\title{
阿波藍国際研修会
}

\section{Awa Natural Indigo International Seminar}

川 人 美洋子

\section{阿波藍国際研修会開催}

徳島県では、阿波藍を取り入れたイベントがよく開催さ れていますが、国際研修会の開催は初めてのことでした。 徳島県では「文化立県とくしま推進会議」が設立され、個 性豊かな文化資源を発信するため四大モチーフ発信事業が 行われています。平成 22 年度の事業として「阿波藍」が 四大モチーフのひとつに選ばれ、今年度は一年を通じて数 多くの阿波藍イベントが行われています。「阿波藍国際研 修会 (主催 : 徳島県・文化立県とくしま推進会議)」はその 中心的なイベントして 11 月 5 日から 8 日までの 4 日間「学 ぶ、語る、考える。藍に浸る 4 日間。」として開催されま した。ここに、報告させていただきます。

\section{阿波藍再考 藍千}

今回の連載の中で、徳島県内のわずか 5 軒の藍師が日本 全国の藍染を支え、その生産量は 1985 年から 2005 年まで 約 1000 俵で安定していると申し上げました。しかしなが ら、数年前より微減し、2007 年より 1000 俵を切っていま す。一過性のもので回復するかと思っていたところ、昨年 度は 828 俵に減少しました。危機的状況ではないものの、 新しい顧客開拓が求められています。

1000 俵の生産と消費が約束されますと阿波藍の伝統が 維持できるのですが、徳島県の藍染関係者には、この事実 が案外知られていません。そこで、今回のプロジェクトで は、藍染めしたものではなく阿波藍染料そのものを取り上 げ、1000 俵の意味を考えていただくために「阿波藍再考 藍千」を揭げ、メインポスターの主役として文化庁から選 定された選定保存技術保持者の方々にお願いしました（図 1)。従来の藍染のポスターと違った視点が斬新でした。

\section{1 日目講義 (11月 5 日)}

初日は海外から 7 名の講師をお招きし、徳島県内の講師

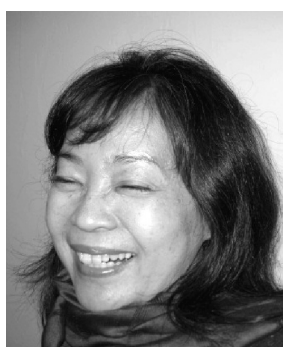

MIYOKO KAWAHITO

徳島県立工業技術センター 専門研究員 工学博士

下770-8021 徳島県徳島市雑賀町西開 11-2

Tel :088-669-4711 Fax:088-669-4755 E-mail : kawa@itc.pref.tokushima.jp 〈専門〉染色化学

〈趣味〉ホームスパン

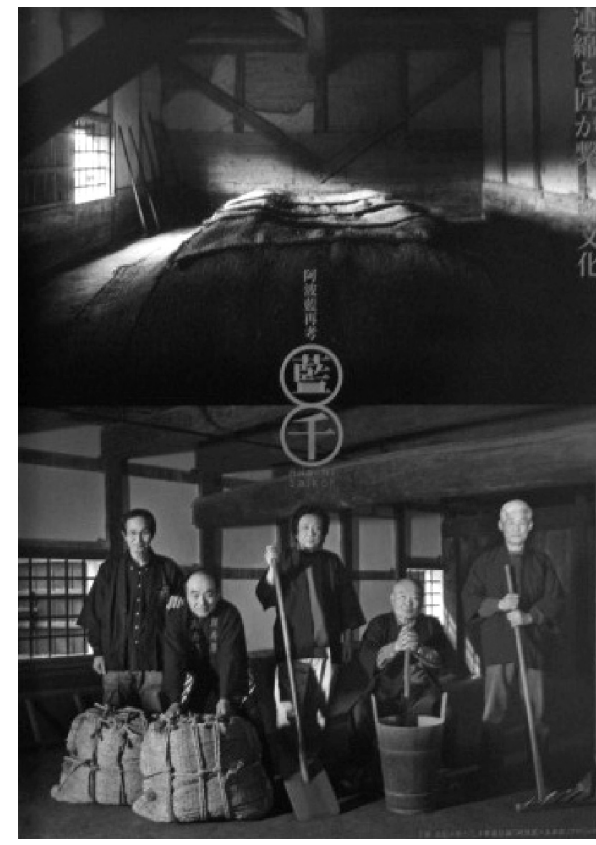

図1メインポスター

（文化立県とくしま推進会議・デザイン：立花かつこ）

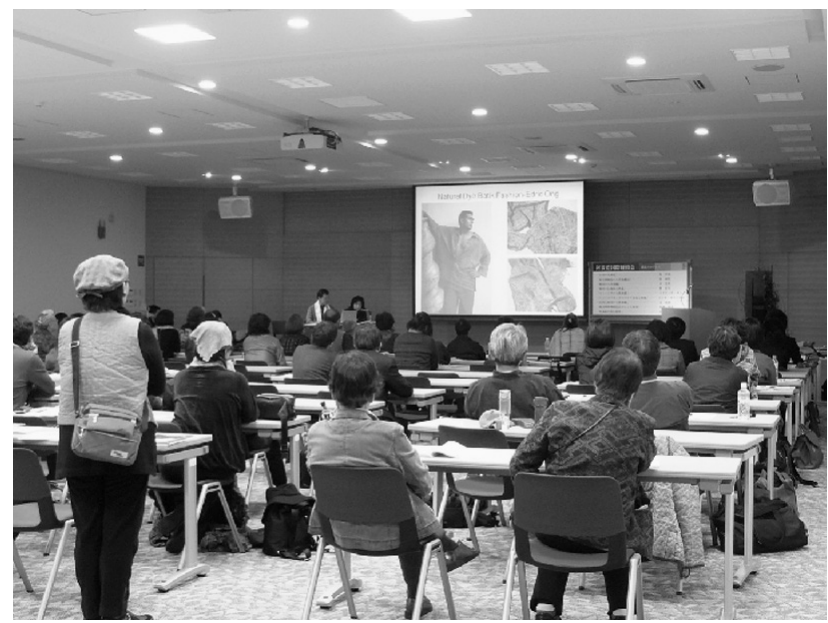

図 2 阿波藍国際研修会・講義

（写真提供：文化立県とくしま推進会議）

2 名を加えて 9 題の発表がありました(図 2$)$ 。まず、台湾 の Fen-mei Ma 氏は台湾国立工芸研究所において長年研究 された台湾の沈殿藍について発表されました。途絶えてい た台湾藍の製造復元から染織方法の標準化、さらに普及の 実例を詳細に述べられました。同じく台湾の Hsiang-Wen Chang 氏は、故宮博物院学芸員の立場から「故宮博物院 
の天然染織品」について、歴史的背景や色について発表さ れました。

韓国からは韓国自然染色美術館館長の Ji-Hee Kim 氏と 韓国重要無形文化財第 115 号染色匠保有者の Kwan-Chae Jung 氏が韓国の天然藍(沈殿藍)の歴史や現状を報告され ました。マレーシアからは、アトリエ・サラワクを主宰し 織物やファッション分野で国際的に活躍されている Edric Ong 氏が天然染織分野のネットワーク構築の重要性を述 ベられました。ニュージーランドの大学で教えている Donna Campbell 氏は、マオリの伝統的な染織を使った衣 服の彫刻を制作している芸術家でもあり、その活動を報告 しました。中国からは台湾や中国で博士号を取得し、現在 は上海で天然染織の衣服を製造販売されている Sung-Hee Kim 氏が、天然染織のファッションへの取り組みを発表 しました。

最後に徳島県からは、徳島城博物館学芸員の根津寿夫氏 が阿波藍の徳島藩での経済的な位置づけを、私が「阿波藍 の色の特性」を発表させていただきました。

6 力国の発表者の共通点は、自国の天然染織の文化や技 法の伝統を守り伝えようと行動していることでした。理論 も重要ですが、実践者の発表には、20 年以上のキャリア を積んだなかで見える重みを感じさせてくれました。日常 生活に、なくてはならないとまでは言えない伝統染織です が、長く続いてきた事実にはその理由があります。深く考 え、知ることの大切さを思う一日でした。

\section{2 日目ワークショップ(11月 6 日)}

2 日目に、徳島県内で阿波藍を使う、キャリア 20 年か ら 30 年以上の染師の方々 4 名を講師としてお迎えした ワークショップが開催されました(図 3)。「阿波藍を使っ た灰汁発酵建て」と「絞り染め」を現代の名工でもある古 庄紀治氏、「型染め」を原田政則(作家名：ふたあい政則は らだ)氏、「筒描染め」を原田史郎氏、「ろうけつ染め」を 林広氏が、それぞれ担当されました。日常的に教えること がない各氏が、今回の研修会のために長年研鑽を積んだ技

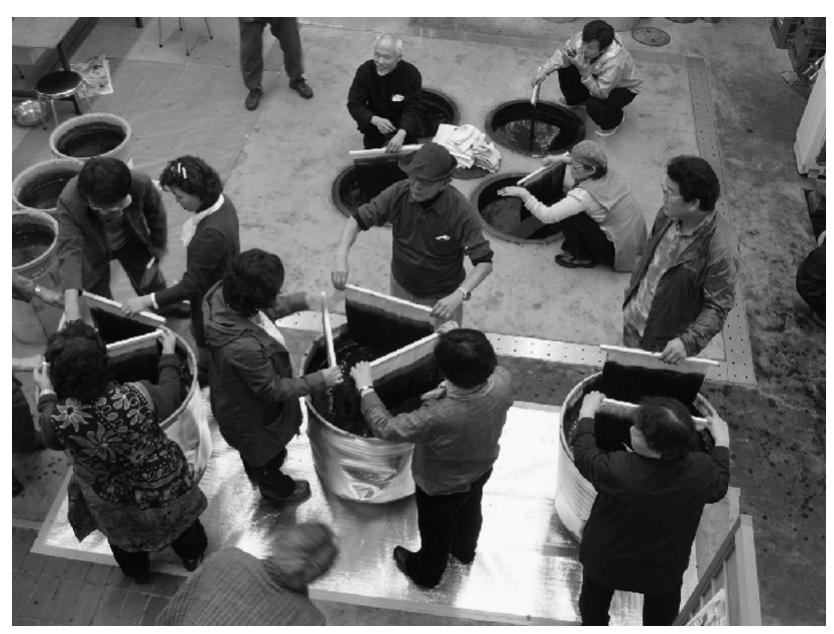

図 3 阿波藍国際研修会・ワークショップ (写真提供：文化立県とくしま推進会議)
術を公開してくださいました。

参加者の中には、阿波藍染めの経験者もいましたが、初 めて触れるプロの技術に興奮を隠せない様子でした。何故 技術を惜しみなく公開できるのか、推測の域を超えないの ですが、いくつかの理由があると思います。まずは、国際 交流のため日本文化のすばらしさを伝えようとされたので しょう。公開しても短期間でマスターできない、といった 自信もあるでしょう。あるいは、消えてしまうならせめて 誰かに伝えたい、といった伝統の厳しい現状からのお気持 ちがあったのかもしれません。

前日の講義の講師の方々や海外招待デザイナーの方々も、 この日は研修生として参加し、楽しい国際交流となりまし た。

\section{3 日目フィールドワーク（11月７日）}

この日は藍関連施設を見学し、最後に藍染ファッション ショーのため徳島城博物館を訪問するフィールドワークが 行われました(図 4)。まず、松茂町にある三木文庫と石井 町の田中家住宅で阿波藍の隆盛を感じ取っていただけたと 思います。いかに阿波藍産業が徳島藩の経済を支え繁栄さ せた産業であったかを、建造物と豊富な資料が物語ってい ます。続いてこの時期にしか見られない阿波藍の製造工程 を藍師外山良治氏の説明とともに見学し、脇町にある観光 拠点うだつの町並みに移動しました。「重要伝統的建造物 群保存地区」に指定されている同町並みに藍商佐直吉田家 住宅がありますが、そこでは「阿波藍×未来形プロジェク 卜展」が開催されていました。阿波藍を使う染師、作家、 企業がそれぞれ和室 1 部屋を使って各々テーマを決めて展 示しました。出展数 24 件は、徳島県でも初めての試みで した。

最後に徳島城博物館の日本庭園でのファッションショー は圧巻でした(図 5)。シーン 1 は、徳島県内のデザイナー や企業のコレクション、シーン 2 は徳島県美容業生活科学 課衛生同業組合による和コレクション、シーン 3 が海外招 待デザイナー 6 名のコレクションでした。海外からは講演

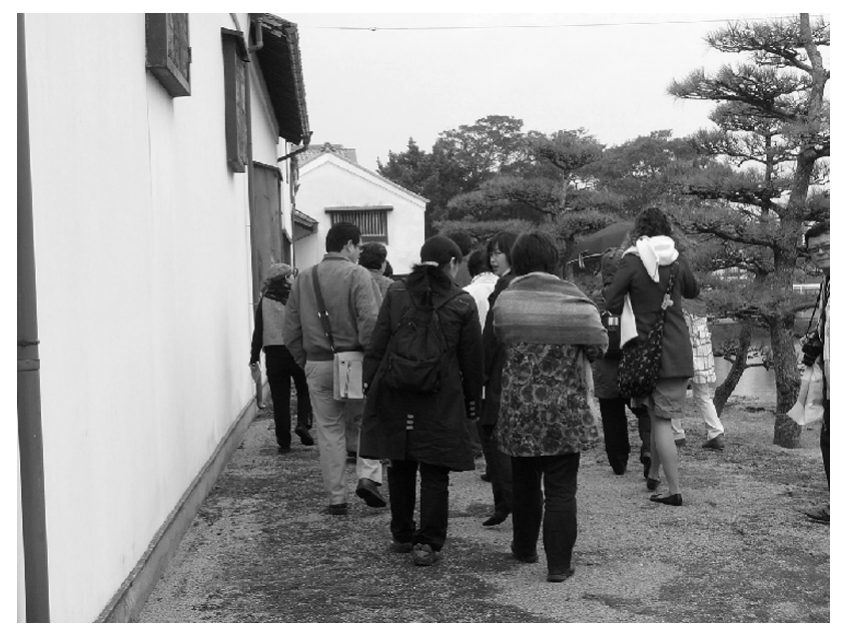

図 4 阿波藍国際研修会・フィールドワーク （写真提供：文化立県とくしま推進会議） 


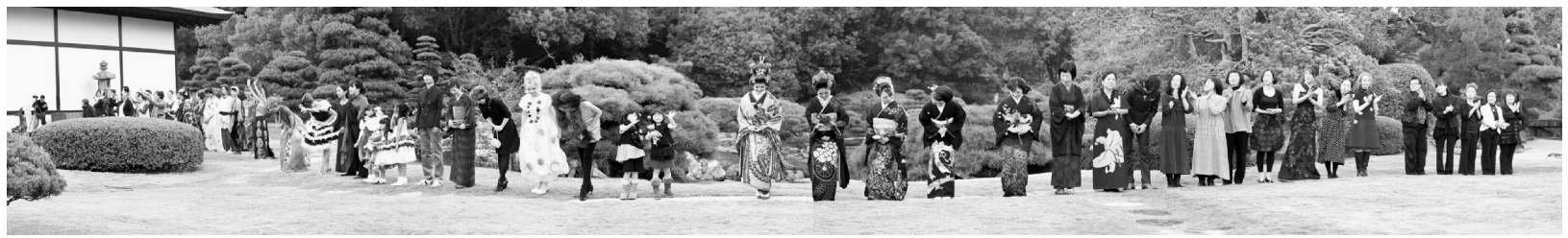

図 5 ファッションショーに参加した全てのデザイナー(写真提供 : Edric Ong 氏)

もお願いした Edric Ong 氏、Ji-Hee Kim 氏、Sung-Hee Kim 氏、Donna Campbell 氏に加え、フィリピンから Alfonso Guino-o 氏と台湾から Sophie Hong 氏が参加されました。 それぞれの国で天然染織を用いている代表的なデザイナー の作品は徳島県内の藍関係者に刺激を与えたように見受け られました。

$$
\begin{gathered}
4 \text { 日目デモンストレーションと } \\
\text { パネルディスカッション (11 月 } 8 \text { 日) }
\end{gathered}
$$

デモンストレーションでは伝統的な阿波藍評価技法であ る「手板法」(佐藤好昭氏)、阿波藍と最も相性のいい素材 である綿の糸作り (高本純氏)、徳島の原始布太布の糸作り (石川文江氏)の実演がそれぞれの専門家によって披露され ました(図6)。

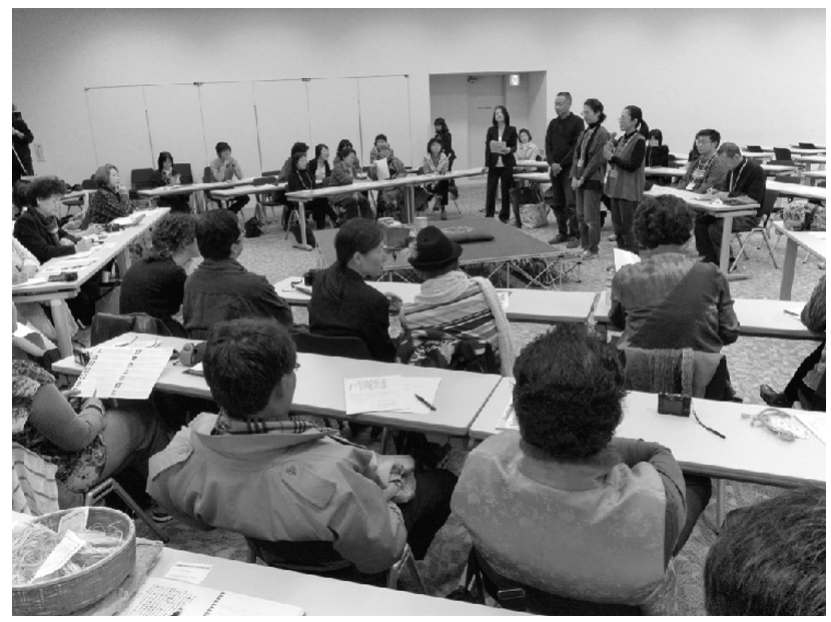

図 6 阿波藍国際研修会・デモンストレーション (写真提供：文化立県とくしま推進会議)

休憩を挟み「これからの阿波藍」をテーマに前述の Fenmei Ma 氏、古庄紀治氏に加え藍師の新居修氏、吉田愛二 氏、デザイナーの立花かつこ氏、文化立県とくしま推進会 議事務局長の鎌田義人氏、同事務局の藤川順子氏をパネ ラーに、パネルディスカッションが開催されました。Fen -mei Ma 氏や立花かつこ氏は、技術的に完成された伝統的 なものづくりには、製品だけでなくプレゼンテーションの 場にもデザインや感性が欠かせないと述べられました。ま た、それを受けて染師である古庄紀治氏もデザインの重要 性を理解していながらも現状は途上であると認識されてい ました。お二人の藍師からは厳しい現状でも今の規模を維 持していく責任感が感じられました。事務局側からは、ネッ トワークの重要性が強調され、この研修会を機会にネット
ワークの構築に協力していきたいとまとめられました。会 場からは、このような研修会の意義と継続希望の声が挙が りました。

\section{会議を終えて}

阿波藍の小さな規模のイベントは数多くありましたので、 これとは違った新しさを示せる研修会にしようと、事務局 が 1 年半をかけて準備してきました。そのため、「阿波藍 ×未来形」プロジェクトと名づけ、新しい阿波藍のファン 作りに努めてきました。

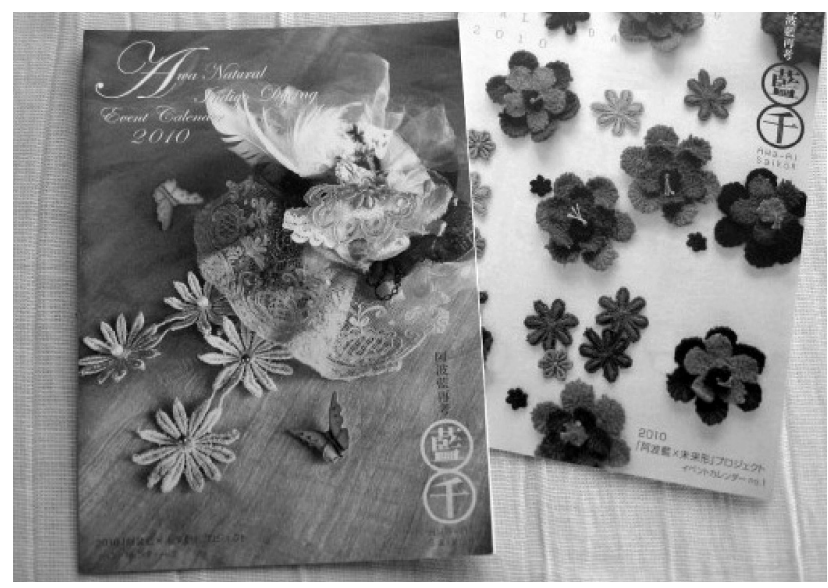

図 7 総合パンフレット(デザイン：立花かつこ)
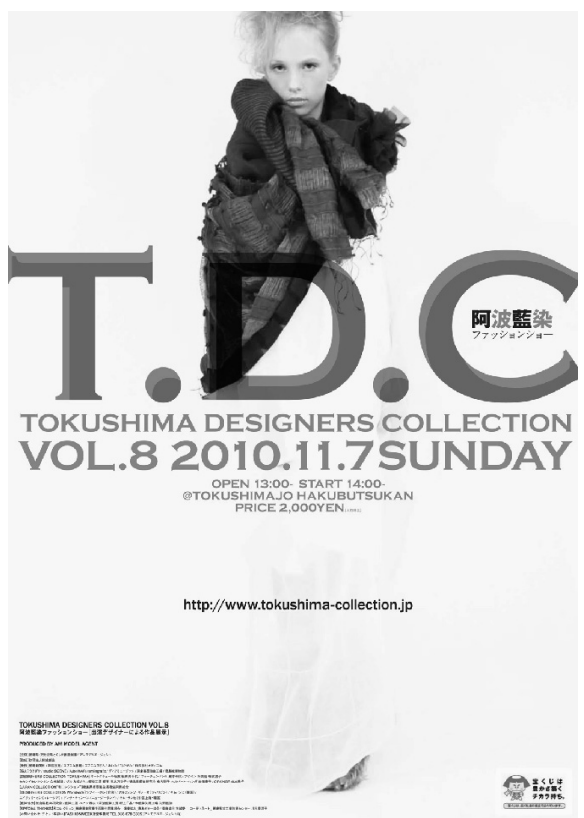

図 8 ファッションショーポスター (提供 : 有限会社アン・モデルエージェント、 写真撮影：中野道広） 
しかしながら、伝統的なものづくりには、長い時間かけ て磨かれた良いものが残っていますので、新しいものづく りは言葉で言うほど簡単ではありません。今回は、試行錯 誤の中で参加者が作品や意見を発表できたと思います。徳 島県内の藍関係者のパネルディスカッションへの参加(平 日)が思ったほど伸びなかったのは、現状の厳しさを考え れば納得せざるを得ませんでした。総合パンフレット(図 7)とファッションショーのポスター(図 8)に、従来の阿波 藍と違った印象を受けたと多くの方が言ってくださったの で、ここに紹介いたします。

\section{謝 辞}

4 月から繊維と工業に「阿波藍」に関して現状や特性を 思いのまま長期にわたって書かせていただき、今回で無事
終了することができました。このような機会を与えてくだ さいました「繊維と工業」の編集者の皆様、特に編集長浦 川宏氏に深く感謝いたします。拙い文章を読んでくださっ た方々にもお礼申し上げます。英語の表題について助言を 頂きました徳島大学の Don Sturge 氏、連載するにあたっ てインタビューに答えてくださった皆様、写真や資料を提 供してくださった皆様、阿波藍関係者の方々、徳島県立工 業技術センターの皆様の支援がなければ連載できませんで した。ありがとうございました。今回の連載に加筆し写真 を加えまとめた「阿波藍」を日本語バージョンと英語バー ジョンの本にまとめることができました。今回のイベント のテキストとして、この本を発行販売してくださった文化 立県とくしま推進会議事務局(電話 088-621-2119)にも感 謝しています。

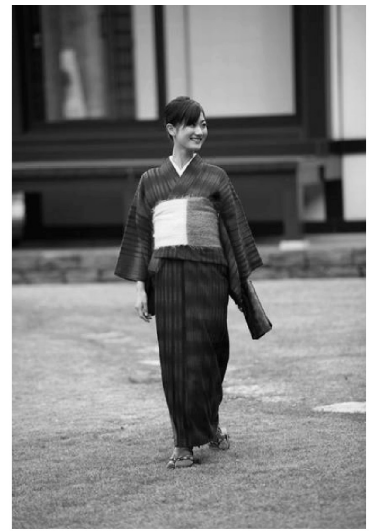

藍染工房藍玉

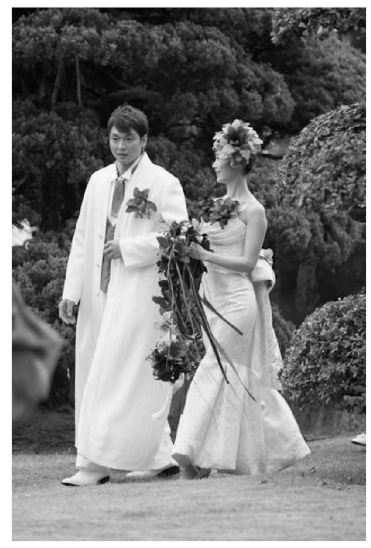

AGAIN amiAi

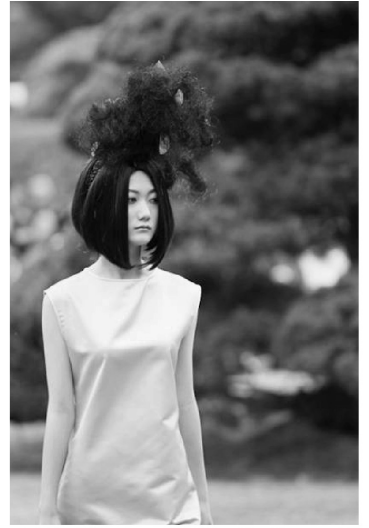

JILL

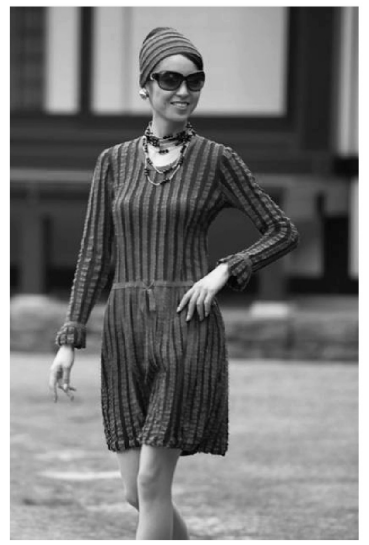

HAUTECOUTURE BANDOH

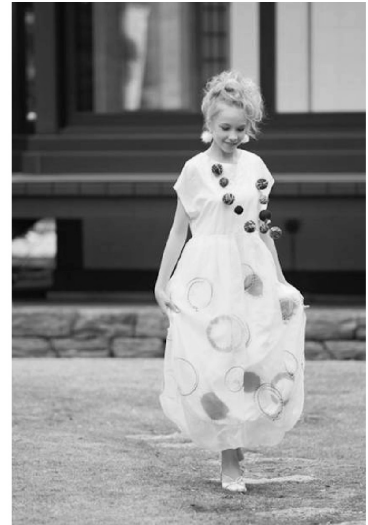

徳島県藍染研究会

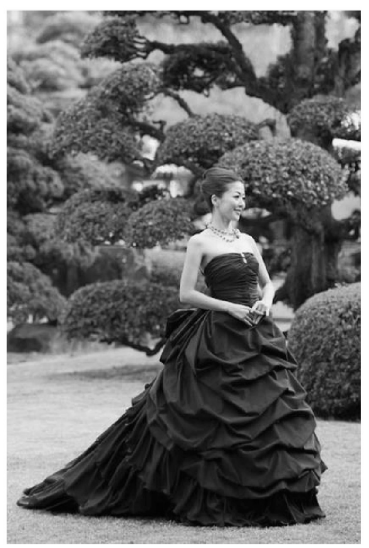

FORTUNE DRESS

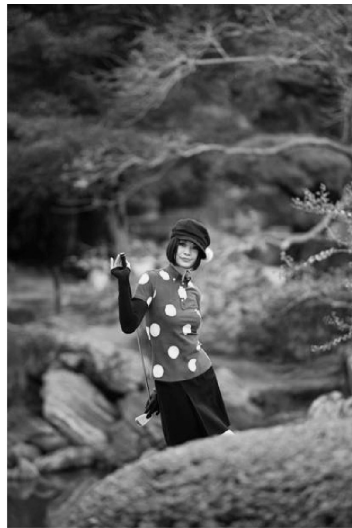

$2^{\text {nd }}$ SELECTION

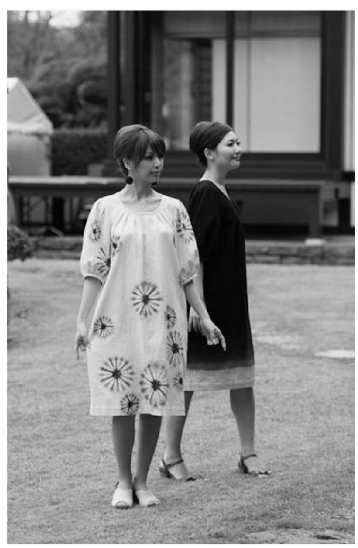

ORANGE

ファッションショー シーン 1 から 写真提供 : 有限会社アン・モデルエージェント 